\title{
Human Effigy Pipes from Spiro Mound, Leflore County, Oklahoma
}

Sarah White

Unknown

Follow this and additional works at: https://scholarworks.sfasu.edu/ita

Part of the American Material Culture Commons, Archaeological Anthropology Commons, Environmental Studies Commons, Other American Studies Commons, Other Arts and Humanities Commons, Other History of Art, Architecture, and Archaeology Commons, and the United States History Commons

Tell us how this article helped you.

This Article is brought to you for free and open access by the Center for Regional Heritage Research at SFA ScholarWorks. It has been accepted for inclusion in Index of Texas Archaeology: Open Access Gray Literature from the Lone Star State by an authorized editor of SFA ScholarWorks. For more information, please contact cdsscholarworks@sfasu.edu. 


\section{Human Effigy Pipes from Spiro Mound, Leflore County, Oklahoma}

Creative Commons License

(c) (i) (8)

This work is licensed under a Creative Commons Attribution-NonCommercial 4.0 International License 


\title{
HUMAN EFFIGY PIPES FROM SPIRO MOUND, LEFLORE COUNTY, OKLAHOMA
}

\author{
Sarah White*
}

Animal and human effigy tobacco pipes are not uncommon in Middle and Lower Mississippi culture sites, but are often rather crudely worked. However, the five human figurine pipes found during the University of Oklahoma - Works Project

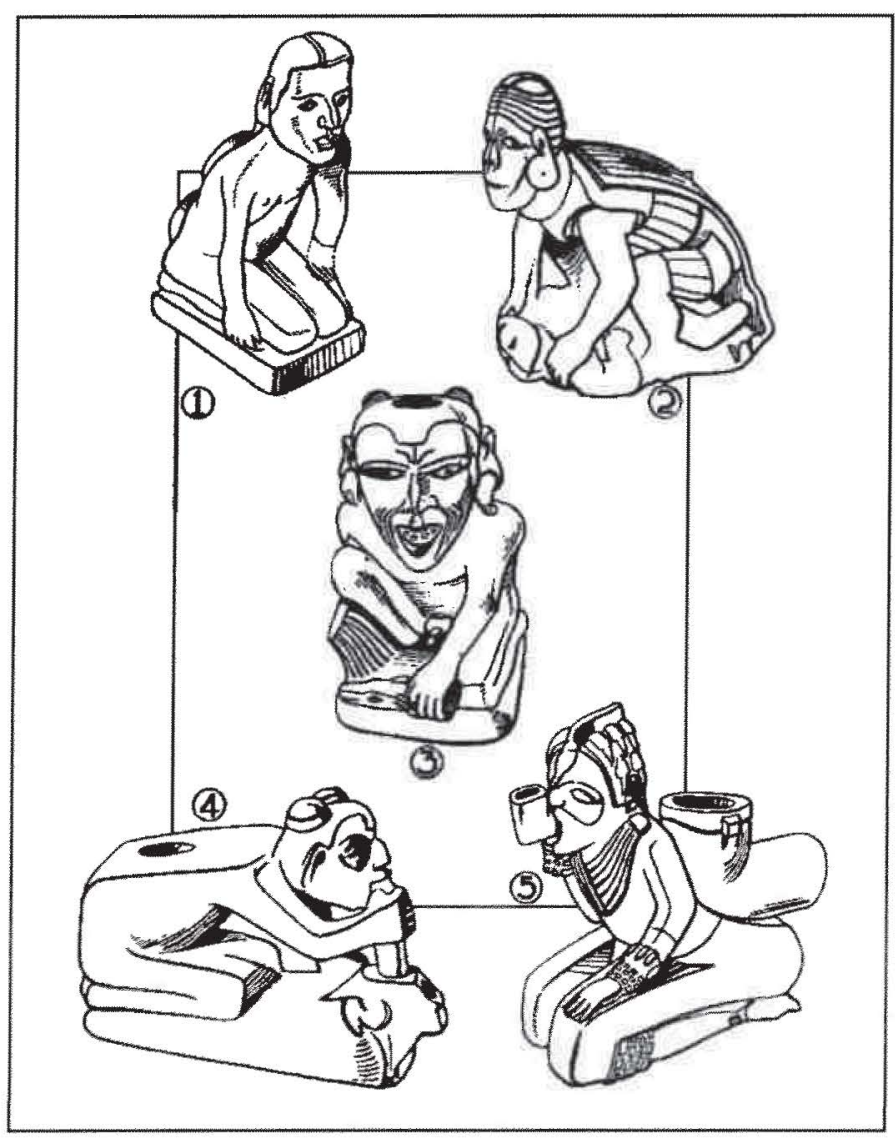

Effigy pipes from Spiro Mound; Figure 1, A9-2; Figure 2, B99-1; Figure 3, B99-3; Figure 4, B99-2; Figure 5, A9-1.
Administration excavation of the Spiro Mound (Ed. note: 34LF46) are unusually perfect specimens of primitive stone sculpture and represent relatively finished examples of prehistoric art. The accompanying pen and ink sketches of these pipes give a general idea of the artistry they represent.

Figures 1 and 5 (A9-1 and A9-2) were found together but were not associated with a burial, while the other three were associations in Burial 99, the richest single feature encountered in the Spiro Mound. These effigy pipes from B99 (Figures 2,3 and 4) were associated with four equal-stemmed "T" shaped pipes and with a mosaic pattern consisting of scores of finely chipped projectile points.

Figure 1 represents a squatting human figure with both the pipe bowl and stem socket carved in the back. The effigy is cut from white chalk having a hardness of 2.5 and is $24.5 \mathrm{~cm}$. in height. A bit of charred tobacco was packed in the bottom of the bowl. The pipe is now in the collection of Mr. Clark Field, Tulsa. Figure 5 is a 
conventionalized kneeling human figure, itself represented as smoking. The pipe is not integrated in the effigy but is carved separately, resting on the back of the sculpture. This specimen is cut from gray silt stone having a hardness of 3.5. Sufficient traces of the original paint remain to reconstruct the color scheme. The body from the waist down was yellow, the torso was brown; but the face, arms and shoulders were black. The wrists and hands were yellow and yellow circles were painted around the eyes. The functional part of the pipe was red and the head dress was red, yellow, white and brown, with a copper sheath along the median crest. This effigy is $22.4 \mathrm{~cm}$. in height.

Figures 2, 3 and 4 were found together and are all carved from a deep red, soft stone which apparently is largely bauxite with an admixture of ferric oxide. It has a hardness of 3 on the standard scale. In all these effigies the functional pipe bowls and stem orifices are integral with the figure itself.

Figure 2 is in a semi-squatting position, bent forward with hands grasping a recumbent figure which is too defaced to be definitely identified. The pipe bowl and stem are in the same positions as those of Figure 4, but the effigy itself is more elaborately decorated and is shown with ear ornaments. Some effigy pipes reported from this region, now in the possession of private collectors or commercial diggers show male and female figures in various postures of coition and some archaeologists are of the opinion this figure is such a representation. It is $27.2 \mathrm{~cm}$. in height, the largest of the group. Figure 3 is the most perfect specimen and still carries a high polish. The figure is represented crouching with one hand and knee on a fallen deer. The ears are embellished with crescent ornaments, the hair is wound in two "horns" on the head and the teeth are pointed. The pipe bowl is in the top of the head and the stem orifice is at the back of the neck. This figurine is carved with greater anatomical detail than any of the others, the primitive sculptor even representing the vertebrae, together with the heavy muscles of the spine, arms and legs. The statuette is $17.7 \mathrm{~cm}$. in height and $14.5 \mathrm{~cm}$. wide. Figure 4 represents a human figure kneeling forward and smoking through a tube placed in the stem orifice of an animal figure pipe. The hair is dressed in two knots or "horns" very similar to the coiffure of Figure 3. The pipe bowl is excavated in the middle of the spine and the stem opening is placed approximately in the anal position. The figure is $20.5 \mathrm{~cm}$. in height.

In general it may be said that while the style of these effigy pipes does not differ in any important respect from those already known in the Lower Mississippi valley, the artistic craftsmanship which they display is distinctly superior.

\footnotetext{
* Museum of Anthropology, University of Oklahoma, Norman.
} 